\title{
KOMUNIKASI ANTARPRIBADI TUNAGRAHITA
}

\author{
Aliyah Nur'aini Hanun \\ Fakultas Ilmu Sosial dan Ilmu Politik Universitas Tanjungpura Pontianak \\ Jalan Ahmad Yani, Pontianak - 78124 Kalimantan Barat Telp. (0561) 739630, Fax: (0561) 739636, \\ HP. 08195660086, email: aliyah nuraini@yahoo.com \\ Naskah diterima tanggal 25 Agustus 2013, disetujui pada tanggal 14 November 2013
}

\section{INTERPERSONAL COMMUNICATION OF CHILDREN WITH MENTAL RETARDATION}

\begin{abstract}
Tunagrahita were a terminology to called the children with mentally retarded conditions. This conditions caused these children having difficulties at least on four areas, related with attention, memory, language, and academics. The research problem is how interpersonal communication tunagrahita in Dormitory Extraordinary Education Foundation (YPLB) Cipaganti Bandung. This research's aim is to seek the interpersonal communication phenomenon of children with mentally retarded in YPLB Cipaganti Dormitory. The research method which were used is the qualitative method with communication Ethnography approach and Symbolic Interactionism theory to have comprehensive descriptions about life reality of mentally retarded's children in YPLB Cipaganti Dormitory. Data obtained by participation observer, unstructured interviews, and documentary study. The result showed that interpersonal interactions are done with each child boarding and with the management of the hostel, is a series of unique events and interpersonal communication with a distinctive circular process that takes place continuously.
\end{abstract}

Keywords: interpersonal communication, tuna grahita, Ethnography study of Communication.

\begin{abstract}
Abstrak
Tunagrahita merupakan istilah yang digunakan untuk menyebut anak yang memiliki kemampuan intelektual di bawah rata-rata. Kecerdasan di bawah rata-rata normal ini menyebabkan tunagrahita mempunyai kesulitan sedikitnya pada empat kawasan yang berkaitan dengan atensi, daya ingat, bahasa, dan akademik. Permasalahan dalam penelitian ini adalah bagaimana komunikasi antarpribadi tunagrahita di Asrama Yayasan Pendidikan Luar Biasa (YPLB) Cipaganti Bandung. Penelitian ini dilakukan untuk menangkap fenomena komunikasi antarpribadi tunagrahita yang terjadi di asrama YPLB Cipaganti. Metode penelitian yang digunakan adalah kualitatif dengan pendekatan Etnografi Komunikasi dan teori Interaksi Simbolik. Teknik pengumpulan data dilakukan dengan pengamatan berperan serta, wawancara, dan dokumentasi. Hasil penelitian menunjukkan bahwa interaksi antarpribadi yang dilakukan anak asrama dengan sesamanya maupun dengan pengurus asrama, merupakan rangkaian peristiwa komunikasi antarpribadi yang unik dan khas dengan proses yang berlangsung secara sirkuler dan terus menerus.
\end{abstract}

Kata kunci: komunikasi antarpribadi, tuna grahita, Etnografi Komunikasi. 


\section{PENDAHULUAN}

Komunikasi, dalam konteks apapun, adalah bentuk dasar adaptasi terhadap lingkungan (Mulyana, 2005). Berbicara mengenai komunikasi, maka tidak akan lepas dari kemampuan berbahasa. Bahasa sebagai pesan komunikasi baik itu verbal maupun nonverbal membutuhkan kemampuan mengabstraksi yang dapat dipenuhi dengan kecerdasan intelegensi yang memadai.

Di kalangan masyarakat awam, kecerdasan mungkin dianggap sama dengan kepintaran, kepandaian, ataupun intelektualitas. Bisa dikatakan bahwa kecerdasan sebenarnya berkaitan erat dengan kondisi mental seseorang. Kondisi ini berada dalam diri seseorang yang jarang tervisualisasi secara fisik. Sesuai dengan fungsinya, mental bagi manusia merupakan pelengkap kehidupan yang paling sempurna, sebagai pengendali motorik tubuh dalam beraktivitas. Oleh karena itu kelainan atau gangguan mental ini pada seseorang (mental subnormal) berarti ia telah kehilangan sebagian besar kemampuan untuk mengabstraksi peristiwa yang ada di lingkungannya secara akurat (Effendi, 2006). Seseorang yang memiliki kelainan mental subnormal ini lazim disebut sebagai keterbelakangan mental, retardasi mental, atau tunagrahita.

Tunagrahita merupakan istilah yang digunakan untuk menyebut anak yang memiliki kemampuan intelektual di bawah rata-rata (Somantri, 2007). Kecerdasan di bawah rata-rata normal ini menyebabkan tunagrahita mempunyai kesulitan sedikitnya pada empat kawasan yang berkaitan dengan atensi (attention), daya ingat (memory), bahasa (language) dan akademik (academics) (Hallahan dan Kauffman, dalam Delphie, 2003).

Berkaitan dengan komunikasi, sebagai modal awal manusia berinteraksi dan beradaptasi, diperlukan kemampuan untuk berbahasa. Untuk mengembangkan kemampuan bahasa dan bicara pada seorang anak normal mungkin tidak menemui kesulitan, karena kecerdasan yang dimiliki sebagai aspek psikologis mempunyai kontribusi cukup besar dalam mekanisasi fungsi kognisi terhadap stimulasi verbal maupun nonverbal, terutama yang memiliki unsur kebahasaan (Efendi, 2006).

Namun, tidak demikian dengan anak tunagrahita, apa yang dapat dilakukan oleh anak normal sulit diikuti oleh anak tunagrahita. Seringkali stimulasi verbal maupun nonverbal dari lingkungannya sulit ditransfer dengan baik oleh anak tunagrahita. Bahkan hal-hal yang tampaknya sederhana terkadang tidak mampu dicerna dengan baik. Belum lagi ditambah faktor fisiologis anak tunagrahita yang cenderung sulit berkomunikasi secara verbal. Hal inilah yang menjadi penyebab ketergantungan tunagrahita terhadap orang lain cukup tinggi.

Anggapan umum masyarakat bahwa anak tunagrahita akan memiliki keterbatasan intelektual seumur hidup sehingga percuma untuk dididik atau dibina, akan membawa dampak negatif bagi anak tunagrahita itu sendiri, dan anggapan itu harus dihilangkan. Mungkin tes IQ bisa dijadikan indikator dari kemampuan mental seseorang. Tetapi, kemampuan adaptif seseorang tidak selamanya tercermin pada hasil tes IQ. Latihan, pengalaman, motivasi, dan lingkungan sosial sangat besar pengaruhnya pada kemampuan adaptif seseorang termasuk komunikasi.

Dalam menghadapi kondisi ini, orangtua dapat meminta bantuan kepada psikolog ataupun pada guru pendidikan luar biasa. Proses adaptif anak tunagrahita harus dimulai dengan proses komunikasi yang baik. Upaya proses komunikasi anak tunagrahita memerlukan pelayanan dan pendidikan yang khusus. Asrama Panti Yayasan Pendidikan Luar Biasa (YPLB) Cipaganti menjadi sebuah tempat penitipan keluarga yang memiliki anak-anak tunagrahita agar anak tersebut dapat dididik dan dibina kemampuan adaptifnya.

Banyak penelitian mengenai anak tunagrahita terutama hanya mengenai masalah klinis maupun ortopedagogik yang berkenaan dengan psikologi dan pendidikan anak. Hal ini dikarenakan masalah ketunagrahitaan hanya dianggap sebagai masalah retardasi mental atau 
keterbelakangan mental, yang lazim berada pada ranah bidang kedokteran, keperawatan, psikologi, maupun pendidikan khusus. Sebagai jembatan multidisiplin ilmu, sebenarnya komunikasi memegang peranan yang sangat penting dalam penanganan tunagrahita, karena perilaku adaptif yang utama adalah bagaimana tunagrahita dapat berkomunikasi dengan lingkungannya. Penelitian ini penting dilakukan mengingat kesulitan berbahasa yang dimiliki oleh anak tunagrahita tidak berarti bahwa mereka hidup dalam "keheningan".

Dalam asrama ini terbentuk peristiwa komunikasi, baik itu antarpribadi tunagrahita maupun dengan pengurus asrama dan lingkungannya yang membentuk suatu masyarakat tutur dengan sistem komunikasi dan budaya keseharian yang khas. Sehingga, rumusan masalah penelitian ini adalah bagaimana komunikasi antarpribadi tunagrahita di Asrama Yayasan Pendidikan Luar Biasa (YPLB) Cipaganti Bandung dengan identifikasi masalah sebagai berikut: (1) Bagaimana jenis peristiwa komunikasi (genre) di asrama? (2) Bagaimana isi pesan (message content) dan bentuk pesan (message form) dalam setiap peristiwa komunikasi? (3) Bagaimana tujuan komunikasi dalam setiap peristiwa komunikasi? (4) Bagaimana setting dalam peristiwa komunikasi? (5) Siapa partisipan yang terlibat dalam peristiwa komunikasi? (6) Bagaimana urutan tindak dan kaidah interaksi yang terjadi dalam setiap peristiwa komunikasi? (7) Bagaimana norma interpretasi dari setiap peristiwa komunikasi?

Tujuan penelitian ini adalah ingin menganalisis mengenai komunikasi antarpribadi tunagrahita di Asrama Tunagrahita YPLB Bandung, menggunakan teori Interaksi Simbolik dan metode Etnografi Komunikasi untuk mendapatkan gambaran utuh mengenai realitas komunikasi antarpribadi tunagrahita di Asrama YPLB Cipaganti. Kegunaaan penelitian ini adalah memberikan masukan bagi masyarakat tentang keberadaan anak tunagrahita yang memerlukan empati, dan juga memberikan masukan kepada instansi terkait dalam mengupayakan sarana yang lebih baik bagi penyandang tunagrahita.

\section{LANDASAN KONSEP}

\section{Kajian Pustaka}

Komunikasi Antarpribadi

Komunikasi antarpribadi merupakan bentuk khusus dari komunikasi manusia yang terjadi ketika manusia berinteraksi secara simultan (simultaneous interaction) dengan orang lain dan saling memengaruhi (mutual influence). Interaksi simultan berarti bahwa partisipan komunikasi bereaksi pada informasi yang sama dalam waktu yang sama. Saling memengaruhi berarti tiap partisipan dipengaruhi oleh interaksi yang terjadi. (Beebe, Beebe dan Redmond, 1994).

Komunikasi antarpribadi juga didefiniskan sebagai komunikasi yang terjadi di antara dua orang yang mempunyai hubungan yang terlihat jelas di antara mereka, misalnya percakapan seorang ayah dengan anak, sepasang suami istri, guru dengan murid, dan lain sebagainya. Dalam definisi ini setiap komunikasi baru dipandang dan dijelaskan sebagai bahan-bahan yang terintegrasi dalam tindakan komunikasi antarpribadi (Devito, 1997).

Mulyana mengatakan, bahwa komunikasi antarpribadi (interpersonal communication) adalah komunikasi antara orang orang secara tatap muka, yang memungkinkan setiap pesertanya menangkap reaksi orang lain secara langsung, baik verbal maupun nonverbal (Mulyana, 2005).

Dapat dikatakan bahwa ketika orang berkomunikasi, maka yang terjadi adalah (1) siapa yang terlibat dalam proses komunikasi saling membutuhkan tanggapan demi suksesnya komunikasi itu, (2) komunikasi melibatkan interaksi dari banyak unsur.

Sementara itu West dan Turner mendefinisikan komunikasi antarpribadi sebagai berikut: "interpersonal communication as the process of message transaction between people to create and sustain shared meaning". Ada tiga komponen penting dalam komunikasi antarpribadi ini yaitu proses, pertukaran pesan, dan makna 
bersama (West dan Turner, 2006).

\section{Komunikasi Verbal}

Komunikasi verbal adalah komunikasi yang menggunakan kara-kata, entah lisan maupun tertulis. Komunikasi ini paling banyak dipakai dalam hubungan antarmanusia. Melalui kata-kata, mereka mengungkapkan perasaan, emosi, pemikiran, gagasan, atau maksud mereka, menyampaikan fakta, data, dan informasi serta menjelaskannya, saling bertukar perasaan dan pikiran, dan lain sebagainya. Benjamin L. Whorf mengemukakan:

Bahasa adalah pandu realitas sosial. Walaupun bahasa biasanya tidak dianggap sebagai hal yang sangat diminati ilmuwan sosial, bahasa secara kuat mengondisikan pikiran kita tentang masalah dan proses sosial. Manusia tidak hanya hidup dalam dunia objektif, tidak hanya dalam dunia kegiatan sosial seperti yang biasa dipahaminya, tetapi ia sangat ditentukan oleh bahasa tertentu yang menjadi medium pernyataan bagi masyarakatnya.Tidak ada dua bahasa yang cukup sama untuk dianggap mewakili kenyataan sosial yang sama. Dunia tempat tinggal masyarakat, bukan semata-mata dunia yang sama dengan mereka yang berbeda (Mandelbhaum, dalam Rakhmat, 1999).

Menurut Larry L. Barker dalam Mulyana (2005), bahasa memiliki 3 fungsi sebagai berikut:

\section{Penamaan (naming/labeling)}

Penamaan merupakan fungsi bahasa yang mendasar. Penamaan atau penjulukkan merujuk pada usaha mengidentifikasi objek, tindakan, atau orang dengan menyebut namanya sehingga dapat dirujuk dalam berkomunikasi.

\section{Interaksi}

Fungsi interaksi menunjuk pada berbagai gagasan dan emosi yang dapat mengundang simpati dan pengertian ataupun kemarahan dan kebingungan.

3. Transmisi informasi.

Fungsi transmisi informasi adalah bahwa bahasa merupakan media untuk menyampaikan informasi kepada orang lain.
Bahasa merupakan media transmisi informasi yang bersifat lintas waktu, artinya melalui bahasa dapat disampaikan informasi yang menghubungkan masa lalu, masa kini, dan masa depan, sehingga memungkinkan adanya kesinambungan budaya dan tradisi.

\section{Komunikasi Nonverbal}

Ray L Birdwhistell mengatakan bahwa $65 \%$ dari komunikasi tatap muka adalah nonverbal. Sementara menurut Albert Mehrabian, 93\% dari semua makna sosial dalam komunikasi tatap muka diperoleh dari isyarat-isyarat nonverbal (Tubbs dan Moss, Sylvia 2005). Proses komunikasi yang menggunakan pesan nonverbal, yaitu meliputi semua pesan yang disampaikan tanpa katakata atau selain dari kata-kata yang dipergunakan. Pesan ini meliputi seluruh aspek nonverbal dalam perilaku manusia: ekspresi wajah, sikap tubuh, nada suara, gerakan tangan, cara berpakaian, dan lain sebagainya (Mulyana, 2005).

\section{Tinjauan Tunagrahita}

Eksistensi anak tunagrahita membawa cerita tersendiri dalam suatu keluarga. Ada orang tua yang menerimanya sebagai takdir, namun ada pula orang tua yang tidak mudah menerima kenyataannya. Reaksi yang muncul, seperti timbulnya perasaan terpukul dan bingung. Dari perasaan-perasaan inilah kemudian timbul reaksi yang beragam, antara lain rasa sedih, rasa bersalah, rasa kecewa, rasa malu dan juga mungkin pada akhirnya pasrah menerima apa adanya.

Tunagrahita terbagi menjadi beberapa kategori yakni:

- Tunagrahita ringan (debil atau mild)

Tunagrahita ringan disebut juga moron. Kelompok ini memiliki IQ antara 68-52 menurut Binet, sedangkan menurut skala Weschler (WISC) memiliki IQ 69-55. Karakteristiknya antara lain kemampuan dalam hal bahasa, pemusatan perhatian, dan akademiknya kurang. Perkembangannya 1/2 hingga $3 / 4$ anak normal seusianya. Penanganannya bisa dengan sering memberikan feedback. Selain itu, dibantu dengan memberikan 
semangat, juga mengulang perbendaharaan kata-kata hingga pengulangan tugas dari yang sederhana ke arah yang lebih sulit. Walaupun demikian, mereka masih dapat belajar membaca, menulis dan berhitung sederhana. Dengan bimbingan dan pendidikan yang baik, anak tunagrahita ringan pada saatnya akan dapat memperoleh penghasilan untuk dirinya sendiri. Pada umumnya anak tunagrahita ringan tidak mengalami gangguan fisik. Mereka secara fisik tampak seperti anak normal pada umumnya (Somantri, 2007).

- Tunagrahita sedang (imbesil atau moderate)

Kelompok ini memiliki IQ 51-36 pada skala Binet dan 54-40 menurut skala Weschler (WISC). Anak terbelakang mental sedang bisa mencapai perkembangan MA sampai kurang lebih 7 tahun (Somantri, 2007). Anak kategori ini hanya bisa menghitung sampai angka 10 , tidak dapat membaca, dan kurang mampu beradaptasi sosial. Sementara perkembangannya sekitar $1 / 4$ hingga $1 / 2$ dari anak normal seusianya. Anak dengan kategori ini bisa diberikan aktivitas sederhana seperti pengulangan kata-kata. Di samping itu, fokus pada program keterampilan seperti menggunting dan mengecat.

- Tunagrahita berat (severe) dan Tunagrahita sangat berat (profound)

Kelompok anak tunagrahita berat sering disebut idiot. Kelompok ini dapat dibedakan lagi menjadi berat dan sangat berat. Tunagrahita berat (severe) memiliki IQ antara 32-20 menurut skala Binet, dan antara 39-25 menurut skala Weschler (WISC). Tunagrahita sangat berat (profound) memiliki IQ di bawah 19 menurut skala Binet dan IQ di bawah 24 menurut skala Weschler (WISC). Kemampuan mental yang dapat dicapai kurang dari tiga tahun. Karakteristiknya, kemampuan berbahasa yang terlambat, bersikap pasif, serta mengalami masalah pada kemampuan motorik kasar dan halus. Penanganannya bisa difokuskan pada perkembangan motorik kasar sebelum motorik halus, atau melatihnya mengidentifikasi warna dan bentuk. Serta pendekatan multisensorik dan konsistensi dalam satu aktivitas. Anak tunagrahita berat memerlukan bantuan perawatan secara total dalam hal berpakaian, mandi, makan, dan lain-lain. Bahkan mereka memerlukan perlindungan dari bahaya sepanjang hidupnya (Somantri, 2007).

\section{Kerangka Pemikiran}

Interaksi Simbolik yang dikenal sebagai perspektif dalam ilmu komunikasi digunakan juga untuk mendasari penelitian ini. Interaksi Simbolik mempelajari sifat interaksi yang merupakan kegiatan dinamis manusia, kontras dengan pendekatan sruktural yang memfokuskan diri pada individu dan ciri-ciri kepribadiannya atau bagaimana struktur sosial membentuk perilaku tertentu individu. Perspektif Interaksi Simbolik memandang bahwa individu bersifat aktif, reflektif, dan kreatif, menafsirkan, menampilkan perilaku yang rumit dan sulit diramalkan.

Teori Interaksi Simbolik adalah suatu teori yang memandang aktivitas manusia sebagai suatu aktivitas yang khas berupa komunikasi dengan menggunakan simbol. Perspektif Interaksionisme Simbolik berada di bawah perspektif Fenomenologis atau perspektif Interpretif (Mulyana, 2006).

Esensi Interaksi Simbolik adalah suatu aktivitas yang merupakan ciri khas manusia yakni komunikasi atau pertukaran simbol yang diberi makna. Menurut teori ini, kehidupan sosial pada dasarnya adalah interaksi manusia dengan menggunakan simbol-simbol yang merepresentasikan apa yang mereka maksudkan untuk berkomunikasi dengan sesamanya, dan juga pengaruh yang ditimbulkan penafsiran atas simbol-simbol ini terhadap perilaku pihakpihak yang terlibat dalam interaksi sosial.

Penelitian ini menggunakan kerangka konsep Etnografi Komunikasi yakni salah satu ancangan yang dapat digunakan di dalam penelitian hubungan bahasa dengan manusia (masyarakat). Pada dasarnya, ancangan itu berusaha memberikan gambaran etnografis 
masyarakat bahasa yang di antaranya mencakup pola komunikasi, fungsi komunikasi, hakikat, dan batasan masyarakat bahasa, alat komunikasi, komponen komunikatif, hubungan bahasa dengan pikiran dan organisasi sosial, dan perilaku bahasa lainnya.

Model Etnografi Komunikasi dikembangkan oleh Dell Hymes pada tahun 1962 dan dikembangkan lebih jauh oleh John Gumperz dan para ahli lainnya pada tahun 1970-an. Ketika itu teori Linguistik didominasi oleh konsep gramatika dan kompetensi bahasa Chomsky, yang gagasannya berfokus pada struktur bahasa daripada penggunaan bahasa.

Etnografi pada dasarnya adalah kegiatan untuk memahami cara orang-orang berinteraksi dan bekerjasama melalui fenomena teramati kehidupan sehari-hari. Harris dalam Creswell (1998) menyatakan bahwa "An ethnography is a description and interpretation of a cultural or social group or system. The researchers examines the group's observable and learned patterns of behavior, customs, and ways of live".

Etnografi Komunikasi memandang komunikasi sebagai proses sirkuler dan dipengaruhi oleh sosiokultural tempat komunikasi itu berlangsung. Untuk mendeskripsikan dan menganalisis komunikasi dalam Etnografi Komunikasi diperlukan pemahaman mengenai unit-unit diskrit aktivitas komunikasi yang memiliki batasan-batasan yang bisa diketahui. Hymes mengemukakan ada tiga unit diskrit aktivitas komunikasi, yaitu situasi, peristiwa, dan tindak komunikasi (Ibrahim, 1992).

Langkah awal untuk mendeskripsikan dan menganalisis pola komunikasi yang ada dalam suatu masyarakat dengan mengidentifikasikan peristiwa-peristiwa komunikasi yang terjadi secara berulang. Langkah selanjutnya menginteventarisasi komponen yang membangun peristiwa komunikasi, kemudian menemukan hubungan antar komponen tersebut (Ibrahim, 1992), dengan mendeskripsikan komponenkomponen penting untuk menganalisis peristiwa komunikatif:

1. Genre atau tipe peristiwa (misalnya lelucon, cerita, ceramah, salam, percakapan)

2. Topik (topic) atau fokus referensi.

3. Tujuan (purpose) atau fungsi (function) peristiwa secara umum dan dalam bentuk tujuan interaksi partisipan secara individual.

4. Setting, termasuk lokasi, waktu, musim, dan aspek fisik situasi itu (misalnya besarnya ruangan, tata letak perabot)

5. Partisipan (participants), termasuk usianya, jenis kelamin, etnik, status sosial, atau kategori lain yang relevan, dan hubungannya satu sama lain.

6. Bentuk pesan (message form) termasuk saluran vokal dan nonvokal, dan hakikat kode yang digunakan (misalnya, bahasa yang mana, dan varietas yang mana).

7. Isi pesan (message content) atau referensi denotatif level permukaan, apa yang dikomunikasikan.

8. Urutan tindakan (act sequence) atau urutan tindak komunikatif atau tindak tutur, termasuk alih giliran dan fenomena overlap percakapan.

9. Kaidah interaksi (rules of interaction) atau properti apakah yang harus diobservasi

10. Norma-norma interpretasi (norms of interpretation) termasuk pengetahuan umum, preposisi kebudayaan yang relevan, atau pemahaman yang sama, yang memungkinkan adanya interferensi tertentu yang harus dibuat, apa yang harus dipahami secara harfiah, apa yang perlu diabaikan, dan lain-lain (Ibrahim, 1992).

Secara singkat, Etnografi Komunikasi merupakan pendekatan terhadap sosiolingusitik bahasa, yaitu melihat bahasa secara umum dihubungkan dengan nilai-nilai sosial dan kultural. sehingga tujuan deskripsi Etnografi adalah untuk memberikan pemahaman global mengenai pandangan dan nilai-nilai suatu masyarakat sebagai suatu cara untuk menjelaskan sikap dan perilaku anggota-anggotanya (Ibrahim, 1992).

\section{METODE PENELITIAN}

Penelitian ini menggunakan pendekatan 
kualitatif yang bertujuan untuk mendapatkan pemahaman tentang kenyataan melalui proses berpikir induktif. Dalam penelitian kualitatif, penulisterlibat dalam situasi dan setting fenomena yang diteliti. Penulis diharapkan selalu memusatkan perhatian pada kenyataan atau kejadian dalam konteks yang diteliti. (Sukidin, 2002).

Penelitian kualitatif bertujuan untuk mendapatkan pemahaman tentang kenyataan melalui proses berpikir induktif. Dalam penelitian kualitatif, penulis terlibat dalam situasi dan setting fenomena yang diteliti. Penulis diharapkan selalu memusatkan perhatian pada kenyataan atau kejadian dalam konteks yang diteliti (Sukidin, 2002).

Secara umum, penelitian kualitatif memiliki ciri, di antaranya: intensif, notes field, analisis data lapangan, tidak ada realitas tunggal, subjektif, realitas dan holistik, depth (dalam). Prosedur penelitian: empiris rasional dan tidak berstruktur. Hubungan antara teori, konsep, dan data memunculkan atau membentuk teori baru (Kriyantono, 2006).

Menurut Lofland dan Lofland dalam Moleong (1993), "Sumber data utama dalam penelitian kualitatif ialah kata-kata dan tindakan selebihnya adalah data tambahan seperti dokumen dan lain-lain". Dalam penelitian ini, sumber data yang berkaitan dengan kata-kata dan tindakan diperoleh melalui subjek penelitian dan informan pengurus asramanya. Subjek penelitian ini adalah seluruh penghuni asrama tunagrahita sebanyak 16 orang.

Dari ke-16 orang tunagrahita di asrama YPLB Cipaganti diindikasikan sebagai tunagrahita ringan atau debil (IQ 69-55) sebanyak 4 orang, dan tunagrahita sedang atau imbesil (IQ 54-40) sebanyak 12 orang. Sedangkan informan yang menjadi sumber data adalah para pengelola asrama, guru, pedagang, hingga pakar, dan psikolog yang dapat mempertajam analisis penelitian ini. Sedangkan objek penelitiannya adalah komunikasi antarpribadi anak tunagrahita.

Teknik pengumpulan data dilakukan melalui pengamatan, wawancara, dan studi dokumentasi. Teknik analisis data yang digunakan dalam penelitian ini adalah mengikuti tiga tahap analisis data yang ditawarkan Miles dan Huberman, yaitu : reduksi data, penyajian (display) data, serta penarikan kesimpulan dan verifikasi (Miles dan Huberman, 1992).

\section{HASIL PENELITIAN DAN PEMBAHASAN}

\section{Hasil Penelitian}

Asrama Tunagrahita YPLB merupakan satu-satunya asrama pendidikan dan pembinaan tunagrahita yang ada di Kota Bandung. Asrama ini berlokasi di Jalan Hegar Asih No.1-3, Cipaganti. Maksud dan tujuan YPLB ialah untuk memberikan pendidikan kepada anak-anak/orang-orang penyandang tunagrahita dan berpartisipasi dalam menanggulangi masalah ketunagrahitaan yakni mendirikan dan menyelenggarakan lembaga pendidikan/sekolah, panti/asrama, serta pusat latihan kerja/keterampilan dan rehabilitasi bagi penyandang tunagrahita.

Suasana kekeluargaan yang kentara di asrama membentuk suasana layaknya rumah sendiri. Ini menjadikan anak-anak asrama seperti berada di lingkungan rumah lengkap dengan orang tua, dan sesama tunagrahita sebagai saudara. Suasana di asrama tergolong sepi, karena dengan luas area hampir satu hektar. Jumlah penghuni asrama 16 orang, pengurus dan keluarganya serta pengawas urusan rumahtangga yang juga menempati area ini. Stigma orang aneh yang melekat pada tunagrahita, sering menjadi penghalang interaksi orang lain dengan tunagrahita.

\section{Pembahasan}

Penelitian ini, menggunakan pendekatan Interaksi Simbolik dan ancangan Etnografi Komunikasi yang terjadi di antara sesama tunagrahita, dapat dilihat keunikan komunikasi anak-anak yang "terperangkap" dalam tubuh orang dewasa.

\section{Tipe Peristiwa Komunikasi (Genre) yang Dilakukan oleh Anak Asrama}

Tipe peristiwa komunikasi (genre) merupakan kategori peristiwa yang terjadi, 
dalam keseharian anak tunagrahita di asrama YPLB Cipaganti, beberapa tipe peristiwa komunikasi yang terjadi adalah: kegiatan sebelum dan sesudah bangun tidur, kemudian percakapan di area kamar mandi, percakapan di waktu makan, baik makan pagi, siang, dan makan malam, percakapan di ruang menonton televisi, kegiatan di koridor asrama, di lapangan dan kegiatan belajar di kelas keterampilan.

Proses komunikasi antarpribadi di tiaptiap tipe peristiwa komunikasi merujuk pada komunikasi diadik (komunikasi antardua orang) dan komunikasi kelompok kecil. Proses komunikasi diadik (dua orang) dapat berlangsung antara pengurus asrama dengan anak asrama, atau antara guru dengan anak asrama, antara tukang masak dengan anak asrama, ataupun antara sesama anak asrama. Komunikasi kelompok kecil dapat berlangsung manakala pengurus asrama memberikan informasi tertentu kepada seluruh anak asrama pada saat di bangsal asrama ataupun menyampaikan instruksi yang harus dipatuhi seluruh anak asrama.

\section{Isi Pesan dan Bentuk Pesan dalam Setiap Peristiwa Komunikasi \\ Isi Pesan}

Isi pesan (message content) berkaitan dengan topik atau fokus referensi dalam peristiwa komunikasi. Berdasarkan pengamatan di asrama, isi pesan anak asrama dalam melakukan komunikasi antarpribadi sesuai dengan tipe peristiwa komunikasi yang terjadi, terlihat dalam Gambar 1.

Setiap hari, anak asrama melakukan topik percakapan yang sama saja atau mengulang kata-kata yang diucapkan, kecuali bila memang ada peristiwa tertentu yang baru, yang dapat mereka bicarakan antara satu sama lain, akan terus dibicarakan sepanjang hari itu. Tapi, karena tunagrahita memiliki masalah dengan ingatan jangka pendeknya, maka peristiwa yang cenderung diingat, justru peristiwa pada waktu yang lampau, yang mereka alami dulu atau justru yang mereka lakukan rutin, sedangkan peristiwa yang tibatiba atau hanya sebentar, akan segera dilupakan.

\section{Bentuk Pesan (message form)}

Bentuk pesan (message form) merupakan cara penyampaian isi pesan dalam peristiwa komunikasi berupa pesan verbal maupun nonverbal. Pesan verbal mengacu pada gramatikal (struktur kata), pemilihan kata (diksi). Pesan nonverbal meliputi kinesik, paralinguistik, sentuhan, proksemik, artifaktual. Anak asrama pada dasarnya mampu merespon peristiwa komunikasi yang terjadi, meskipun tidak semua anak asrama

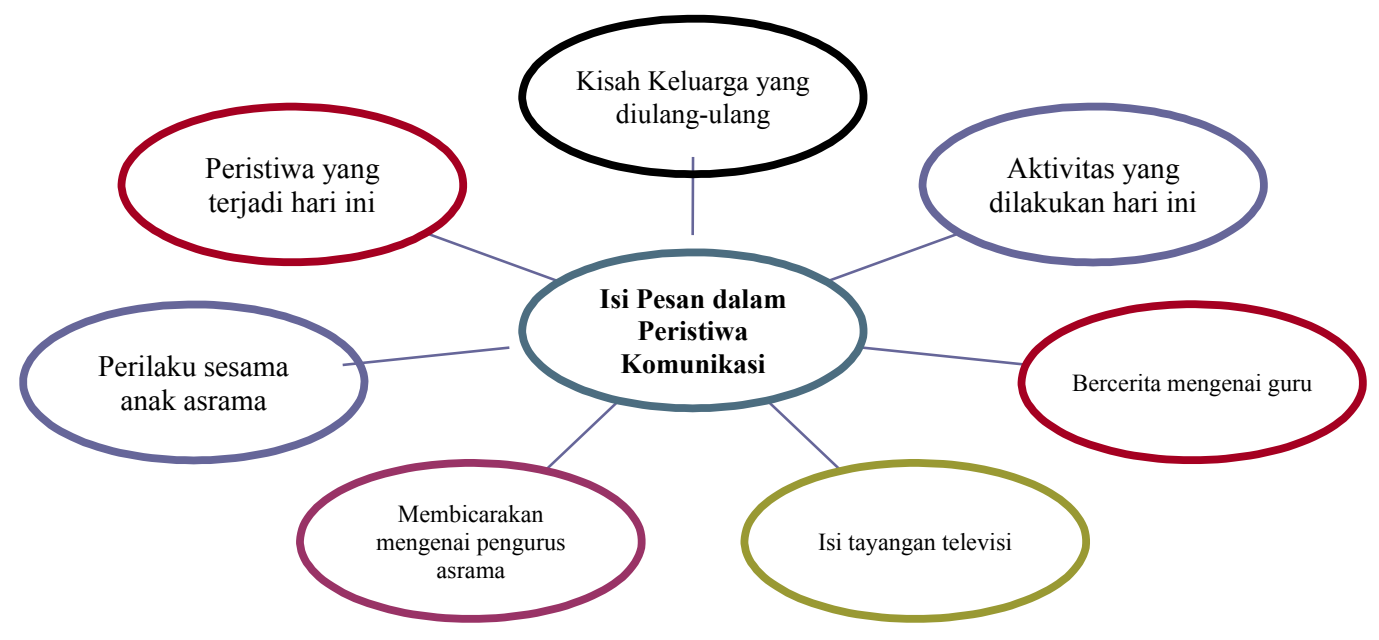

Gambar 1

Diagram Isi Pesan dalam Peristiwa Komunikasi di Asrama YPLB Cipaganti 
mampu berbicara secara verbal dengan baik. Sebagian dari mereka dapat memberikan respon berupa support (penerimaan, menyetujui pernyataan sebelumnya yang dilontarkan), dapat pula nonsupport (tidak setuju, atau menolak), menjawab pertanyaan, menjalankan instruksi ataupun perintah yang disampaikan meski kadang harus disampaikan berkali-kali baru mereka mengerti.

Dengan karakter kemampuan berkomunikasi secara verbal yang berbedabeda, karakterisitik pesan verbal di asrama memiliki kesamaan dalam hal:

1. Kemampuan tata bahasa (sintaksis) yang rendah;

2. Variasi perbendaharaan kata terbatas;

3. Pemilihan kata (diksi) yang sederhana;

4. Struktur kalimat (gramatikal) tunggal, bukan kalimat majemuk;

5. Pengulangan kata dan kalimat (repetisi);

6. Makna kata denotatif dan konotatif.

Sedangkan dalam komunikasi antarpribadi di asrama tunagrahita YPLB Cipaganti, komunikasi nonverbal atau interaksi nonsimbolik lebih banyak terlihat, sebagai reaksi suka-tidak suka, mau-tidak mau, mengerti-tidak mengerti, tahu-tidak tahu, dan lain sebagainya. Pesan nonverbal di asrama tunagrahita YPLB Cipaganti, fungsi yang diutarakan oleh Knapp dalam Rakhmat (1999) juga terlihat dalam penyampaian dan penerimaan pesan nonverbal tersebut yaitu:

1. Repetisi, mengulang kembali gagasan yang sudah disajikan secara verbal, misalnya ketika ditanyakan "sudah makan atau belum?", maka akan dijawab "sudah", dengan menganggukkan kepala berkali-kali.

2. Subtitusi, menggantikan lambang-lambang verbal. Misalnya, tanpa berkata apa-apa, anak asrama menunjukkan tidak mau dengan menggelengkan kepala.

3. Komplemen, melengkapi, dan memperkaya makna pesan nonverbal. Misalnya: anak asrama menangis karena diganggu oleh anak asrama lainnya. Mencibir bila dimarahi pengurus asrama.

4. Aksentuasi, menegaskan pesan verbal atau menggarisbawahinya. Misalnya, anak asrama yang marah mampu untuk menggebrak meja, menendang pintu, memukul anak asrama yang lain, atau mengacungkan kepalan tangan dan jarinya, mengatakan "tidak mau" kemudian pergi.

Di antara fungsi yang diutarakan oleh Knapp itu, ada satu fungsi yang tidak dimiliki oleh anak tunagrahita yaitu, fungsi kontradiksi atau menolak pesan verbal atau memberikan makna yang lain terhadap pesan verbal. Hal ini disebabkan, karena secara psikologis, anak tunagrahita tidak mampu untuk "berpura-pura" dalam komunikasi verbal yang berlawanan dengan komunikasi nonverbalnya. Anak tunagrahita adalah anak yang "jujur" dalam berperilaku.

\section{Bentuk Komunikasi Nonverbal Anak Asrama}

1. Pesan kinesik dengan melihat pesan fasial, gestural, dan postural, yang menunjukkan gerakan sebagian anggota badan seperti wajah, mata, dan tangan untuk mengomunikasikan berbagai makna, seperti mendorong/membatasi, menyesuaikan/mempertentangkan,

responsif/tidak, perasaan positif/negatif, memerhatikan/tidak, melancarkan/tidak reseptif, menyetujui/menolak. Pesan postural berkenaan dengan keseluruhan anggota badan (Rakhmat, 1999).

2. Paralinguistik, misalnya kecepatan berbicara, nada (tinggi atau rendah), intensitas (volume) suara, intonasi, dialek, suara terputus-putus, suara yang gemetar, suitan, siulan, tawa, erangan, tangis, gerutuan, gumaman, desahan, dan sebagainya (Mulyana, 2005).

3. Proksemik disampaikan melalui pengaturan jarak dan ruang. Edward T. Hall dalam Griffin (2006) membagi empat macam ragam jarak komunikasi,yaitu jarak intim (0-18 inchi), jarak pribadi (18 inchi-4 kaki), jarak sosial (4-10 kaki) dan jarak publik (lebih dari 10 kaki).

4. Artifaktual melalui penampilan, tubuh, 
pakaian dan kosmetik dalam upaya membentuk citra tubuh dengan pakaian dan kosmetik (Rakhmat, 1999).

5. Sensitivitas kulit atau sentuhan, merujuk pada lima kategori sentuhan Heslin dalam Mulyana (2001) yaitu fungsionalprofesional, sosial-sopan, persahabatankehangatan, cinta-keintiman, dan rangsangan seksual.

\section{Tujuan atau Fungsi Komunikasi dalam Setiap Peristiwa Komunikasi}

Gorden dalam Mulyana (2005) menyebutkan empat fungsi komunikasi yakni komunikasi sosial, komunikasi ekspresif, komunikasi ritual, dan komunikasi instrumental.

Dalam tipe peristiwa komunikasi yang bervariasi di asrama YPLB, komunikasi sosial dilakukan dengan tujuan untuk mengisi waktu, atau hanya sekedar memuaskan diri dengan berbicara dan didengarkan orang lain.

Tujuan atau fungsi komunikasi ekpsresif juga berlaku bagi anak asrama yang melakukan interaksi dan komunikasi antarpribadi dengan orang lain, misalnya komunikasi yang dilakukan saat bertanya dengan tukang masak, mengenai menu masakan dan apa rasanya. Ekspresi anak asrama juga terlihat manakala mereka saling berbagi informasi mengenai kejadian yang terjadi hari itu. Ataupun bila mereka sudah bercerita mengenai keluarga, bertanya, atau hanya sekedar berceloteh agar didengarkan orang lain. Tujuan anak asrama berkomunikasi saat itu, hanya ingin diperhatikan oleh orang lain. Bila yang diajak bicara menanggapi ceritanya, maka ia akan terus-terusan bercerita.

Erat kaitannya dengan komunikasi ekspresif adalah komunikasi ritual yang biasanya dilakukan secara kolektif. Mulyana mengatakan:

"Bahwa hingga kapanpun ritual
tampaknya akan tetap menjadi
kebutuhan manusia, meskipun
bentuknya berubah-ubah, demi
pemenuhan jati dirinya sebagai
individu, sebagai anggota komunitas
sosial, dan sebagai salah satu unsur dari

alam semesta. Salah satu ritual modern ini adalah olah raga" (Mulyana, 2005).

Hal ini juga berlaku di asrama, di mana pada saat di lapangan, saat olahraga dan bermain, merupakan ritual kolektif yang menjadi kesehariaan anak asrama baik pagi maupun sore hari, untuk mendapatkan kesenangan pribadi maupun bersama-sama. Di antara tujuan atau fungsi komunikasi yang diutarakan, fungsi komunikasi yang keempat, yaitu komunikasi instrumental terutama berlaku bagi pengurus asrama dan sebagian anak asrama yang sering menginstruksikan anak asrama yang lain agar patuh kepadanya. Tujuan atau fungsi dalam setiap peristiwa komunikasi di asrama dapat ditunjukkan dalam gambar 2 .

Bila diringkas, maka ke semua tujuan tersebut dapat disebut membujuk (bersifat persuasif), karena dalam asrama YPLB Cipaganti, percakapan-percakapan yang dilakukan, instruksi yang sudah dikerjakan, ataupun perilaku anak asrama yang ditunjukkannya dengan bertanya mengenai sesuatu, berbagi informasi mengenai kejadian hari itu, mengetahui tayangan film, hingga sekedar mengetahui menu makanan, pada dasarnya mengharapkan respon dari orang lain, seperti memberikan reward berupa katakata pujian ataupun ia mendapatkan kebahagiaan dengan didengarkan oleh orang lain.

\section{Setting dalam Peristiwa Komunikasi}

Setting juga merupakan salah satu aspek yang relatif menjadi perhatian anak tunagrahita di asrama, karena dengan setting yang ada, mereka dapat saling berdekatan, berinteraksi, bersosialisasi, dan berkomunikasi antara satu sama lain. Menurut Mulyana (2000), bahwa komunikasi terjadi dalam konteks ruang dan waktu. Komunikasi tidak berlangsung dalam ruang hampa sosial, melainkan dalam konteks atau situasi tertentu. Konteks di sini berarti semua faktor di luar orang-orang yang berkomunikasi. Konteks di asrama yang memengaruhi anak-anak dalam melakukan komunikasi antarpribadi yakni, pertama, aspek yang bersifat fisik seperti iklim, cuaca, bentuk ruangan, jumlah peserta 


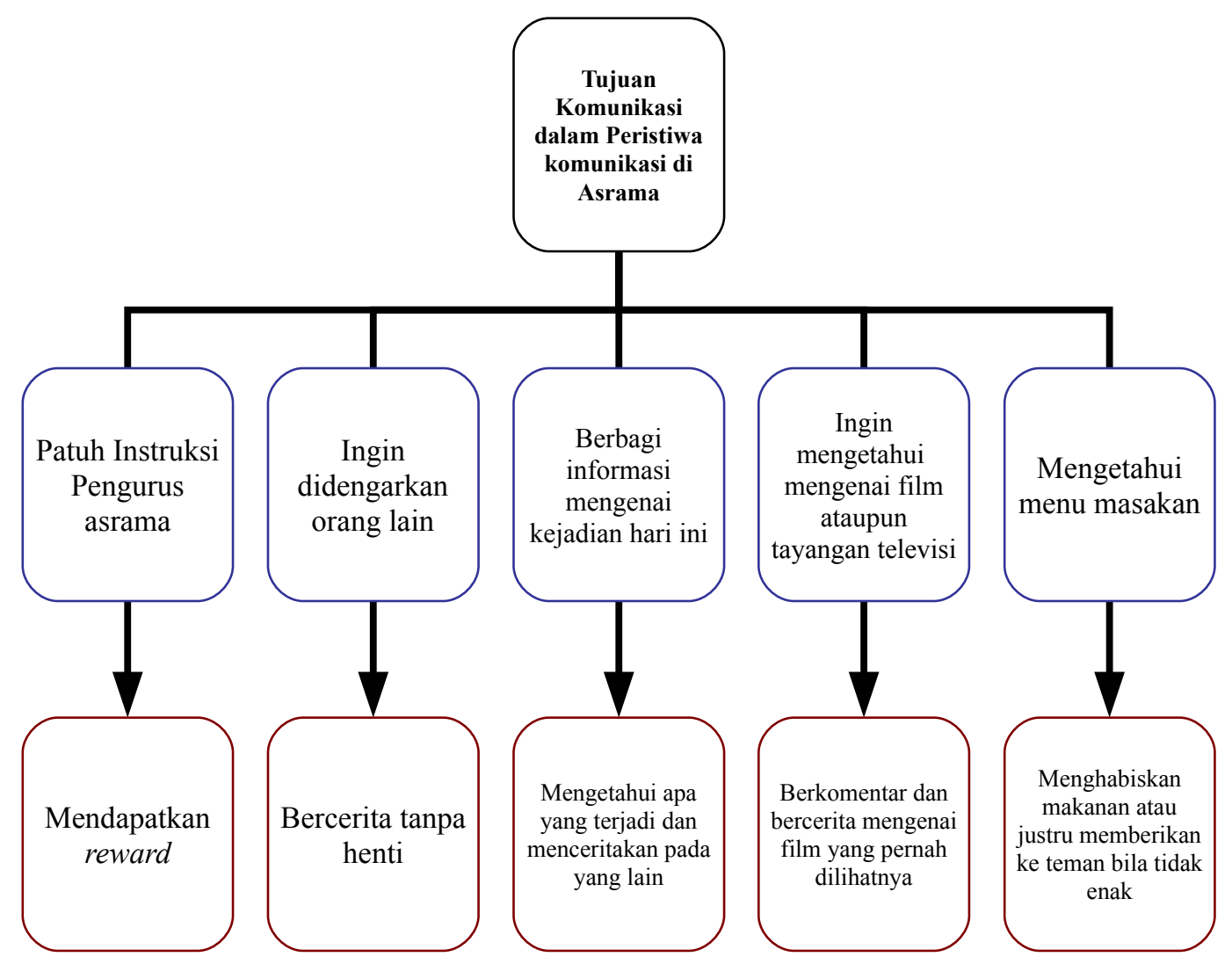

Keterangan: $\sqrt{\text { menunjuk pada respon yang dilakukan anak asrama setelah tujuan komunikasi yang dilakukannya }}$

Gambar 2

Skema Tujuan Komunikasi dalam Setiap Peristiwa Komunikasi di Asrama

komunikasi, penataan tempat duduk. Kedua, aspek psikologis, seperti sikap, kecenderungan, prasangka, dan emosi para peserta komunikasi. Tetapi aspek ini hanya berpengaruh pada anak tertentu saja. Sedangkan aspek sosial, seperti norma kelompok, nilai sosial, dan karakteristik budaya, sama sekali tidak memengaruhi anak asrama, karena mereka tidak mengerti dengan norma maupun nilai sosial. Sedangkan aspek waktu, juga tidak memengaruhi kapan mereka mau bercerita. Dengan cerita yang sama, dapat mereka ulangi mulai dari pagi, hingga malam hari, dan begitu seterusnya.

\section{Partisipan yang Terlibat dalam Peristiwa Komunikasi}

Partisipan mengacu pada individu- individu yang terlibat dalam peristiwa komunikasi, termasuk usianya, jenis kelamin, atau kategori lain yang relevan. Partisipan komunikasi di asrama bervariatif tergantung pada peristiwa komunikasi yang terjadi. Di asrama YPLB Cipaganti, anak asrama merasa dapat leluasa bersosialisasi dengan temanteman senasib dan berinteraksi dengan orang normal lainnya tanpa peduli dengan cacat yang mereka alami, karena mereka di sini merasa tidak berbeda dengan yang lain.

\section{Urutan Tindak dan Kaidah Interaksi yang Terjadi dalam Peristiwa Komunikasi Urutan Tindak (Act Sequence)}

Komunikasi yang terjadi pada anak tunagrahita di asrama YPLB Cipaganti juga mengenal konsep urutan tindak, karena mereka mampu untuk berkomunikasi secara 
aktif, walaupun tidak semua anak asrama mampu melakukannya, karena ada beberapa anak yang tidak mampu berkomunikasi secara verbal dengan baik. Hal ini menunjukkan anak asrama mampu untuk memahami urutan tindakan, karena urutan kegiatan merupakan sesuatu yang sangat penting dalam pendidikan dan pembinaan anak tunagrahita.

\section{Kaidah Interaksi (Rules of Interaction)}

Kaidah interaksi mencakup penjelasan tentang kaidah-kaidah penggunaan tutur yang bisa diterapkan pada peristiwa komunikasi. Kaidah interaksi mengacu pada ketentuan tentang bagaimana orang harus bertindak dalam hubungannya dengan nilai-nilai yang diketahui oleh masyarakat tutur (Ibrahim, 1992).

Interaksionisme Simbolik menunjukkan arti penting dari interaksi dan makna dalam kehidupan manusia, sedangkan Rules theory memberikan bentuk dan substansi pada hubungan interaksi makna ini. Untuk mengetahui suatu aturan dengan tepat, kita harus dapat mengenal konteksnya dan perilaku yang diwajibkan, disukai ataupun dilarang. Aturan juga harus dinyatakan dalam suatu bentuk yang menunjukkan bahwa aturan tersebut memungkinkan untuk ditaati.

Shimanoff dalam Sendjaja (1994) menyatakan bahwa format "jika maka" akan membantu mengidentifikasi aturan melalui komponen-komponen berikut: "Jika...,maka seseorang (harus, tidak boleh, seharusnya)....." Format ini menunjukkan sifat dari ketentuan dan perilaku yang ditentukan. Mereka mengerti kaidah yang ditentukan asrama, meskipun pengurus asrama juga harus mengingatkan hal yang sama setiap hari, agar kaidah itu menjadi kebiasaan hidup anak asrama. Kaidah-kaidah ini berfungsi sebagai tata aturan bagaimana anak harus berinteraksi dengan orang lain.

\section{Norma Interpretasi dari Setiap Peristiwa Komunikasi}

Interpretasi merupakan apa yang dipandang sebagai sesuatu yang tersirat mencakup upaya memahami apa yang disampaikan di luar apa yang ada dalam kata- kata aktual (Ibrahim, 1992). Komponen norma interpretasi haruslah bisa memberikan semua informasi lain mengenai masyarakat tutur dan kebudayaannya yang diperlukan untuk memahami peristiwa komunikasi.

$$
\text { Interpretasi pada komunikasi }
$$
antarpribadi tunagrahita di asrama YPLB Cipaganti tersirat di balik pesan verbal maupun peraturan tertulis asrama dan selalu dicoba untuk diterapkan agar anak mengerti dengan aturan dan norma. Namun, hal ini tidak mudah, karena anak tunagrahita adalah anak yang kondisi kecerdasannya jauh di bawah rata-rata dan ditandai oleh keterbatasan intelegensi dan ketidakcakapan dalam interaksi sosial (Somantri, 2007), termasuk dalam memahami norma dan aturan.

\section{Analisis Etnografi Komunikasi dan Interaksi Simbolik dalam Komunikasi Antarpribadi Tunagrahita di Asrama YPLB Cipaganti}

Dalam asrama YPLB Cipaganti, penggunaan studi Etnografi dilakukan untuk mengungkap atau mengartikan perilaku kelompok tunagrahita sebagai anak asrama yang dipelajari. Frey dalam Mulyana 2006) menyatakan bahwa Etnografi digunakan untuk meneliti perilaku manusia dalam lingkungan spesifik alamiah. Etnografer berusaha menangkap sepenuh mungkin, dan berdasarkan perspektif orang yang diteliti, cara orang menggunakan simbol dalam konteks spesifik.

Keadaan yang terjadi di asrama YPLB Cipaganti merupakan rangkaian peristiwa komunikasi yang melibatkan interaksi simbolik. Ini sesuai dengan tujuh prinsip yang menjadi inti dari teori Interaksionisme Simbolik seperti yang diformulasikan oleh Ritzer dalam Mulyana (2006), yaitu :

1. Manusia, tidak seperti hewan lebih rendah, diberkahi dengan kemampuan berpikir. Anak tunagrahita, meski memiliki kemampuan berpikir yang rendah, namun tetaplah manusia yang layak untuk mendapatkan perlakuan yang sama.

2. Kemampuan berpikir itu dibentuk oleh 
interaksi sosial. Anak asrama mengembangkan kemampuan berpikirnya melalui interaksi dan komunikasi, sebagai suatu proses untuk mengembangkan kemampuan adaptifnya agar mampu bersosialisasi dengan orang lain maupun masyarakat.

3. Dalam interaksi sosial orang belajar makna dan simbol yang memungkinkan mereka menerapkan kemampuan khas mereka sebagai manusia, yakni berpikir. Anak asrama, dengan segala keterbatasannya juga mempelajari makna dan simbol yang diajarkan oleh pengurus asrama, bagian rumahtangga, dan lingkungannya, yang kemudian diterapkannya dalam berkomunikasi dan bersosialisasi dengan orang lain untuk mencapai tujuan komunikasi yang diharapkannya.

4. Makna dan simbol memungkinkan orang melanjutkan tindakan (action) dan interaksi yang khas manusia. Alhasil, makna dan simbol yang anak asrama YPLB pahami, memungkinkannya untuk melakukan tindakan dan interaksi khas manusia seperti melakukan percakapan, bercanda, berkomentar, mengharapkan pujian dan reward.

5. Orang mampu memodifikasi atau mengubah makna dan simbol yang mereka gunakan dalam tindakan dan interaksi berdasarkan interaksi mereka atas situasi. Memang anak tunagrahita di asrama adalah anak yang "dibentuk" dengan kebiasaan dan rutinitas harian yang selalu sama, maka kemampuan untuk memodifikasi atau mengubah makna, cenderung tidak dapat mereka lakukan. Meskipun tidak menutup kemungkinan, ada anak asrama yang masih muda mampu untuk melakukannya.Orang mampu melakukan modifikasi dan perubahan ini karena, antara lain, kemampuan mereka berinteraksi dengan diri sendiri, yang memungkinkan mereka memeriksa tahapan-tahapan tindakan, menilai keuntungan dan kerugian relatif, dan kemudian memilih salah satunya. Istilah early interferention juga berlaku bagi anak tunagrahita, dimana pendidikan dan pembinaan kemampuan adaptif, termasuk mengajaknya berkomunikasi sejak dini, memberikan alternatif pilihan ketika berkomunikasi, akan dapat mengembangkan kemampuannya saat dewasa secara usia. Mereka mampu untuk melakukan modifikasi dan perubahan berdasarakan kebiasaan baru yang mereka lakukan.

6. Pola-pola tindakan dan interaksi yang jalin menjalin ini membentuk kelompok dan masyarakat. Dalam asrama YPLB Cipaganti ini, kebersamaan yang terjalin terus menerus, dalam hitungan hari, bulan, hingga bertahun-tahun menjadikan anak asrama sebagai suatu kelompok masyarakat tutur dan budaya yang unik dalam tataran luas masyarakat Kota Bandung.

Melalui penelitian ini, terlihat bahwa interaksi antarpribadi yang dilakukan anak asrama dengan sesamanya maupun dengan pengurus asrama, merupakan rangkaian peristiwa komunikasi antarpribadi yang unik dan khas. Meskipun mereka tersembunyi dan termarginalkan, tetapi kehidupan di dalam asrama menunjukkan bahwa orang-orang yang memiliki kecerdasan rendah pun mampu berinteraksi dan bersosialisasi dengan membentuk kesepahaman bersama sebagai inti dari komunikasi, walaupun dalam "kacamata" orang dengan kecerdasan normal, proses komunikasi dan perilaku mereka sangat sederhana dan "kekanak-kanakan".

Sehingga dengan pendekatan Etnografi Komunikasi dan Interaksi Simbolik yang digunakan dalam penelitian ini, pada akhirnya dapat menjelaskan fenomena komunikasi antarpribadi tunagrahita di asrama Yayasan Pendidikan Luar Biasa (YPLB) Cipaganti Bandung.

Skema Etnografi Komunikasi antarpribadi tunagrahita di asrama YPLB Cipaganti dapat digambarkan seperti pada gambar 3 . 


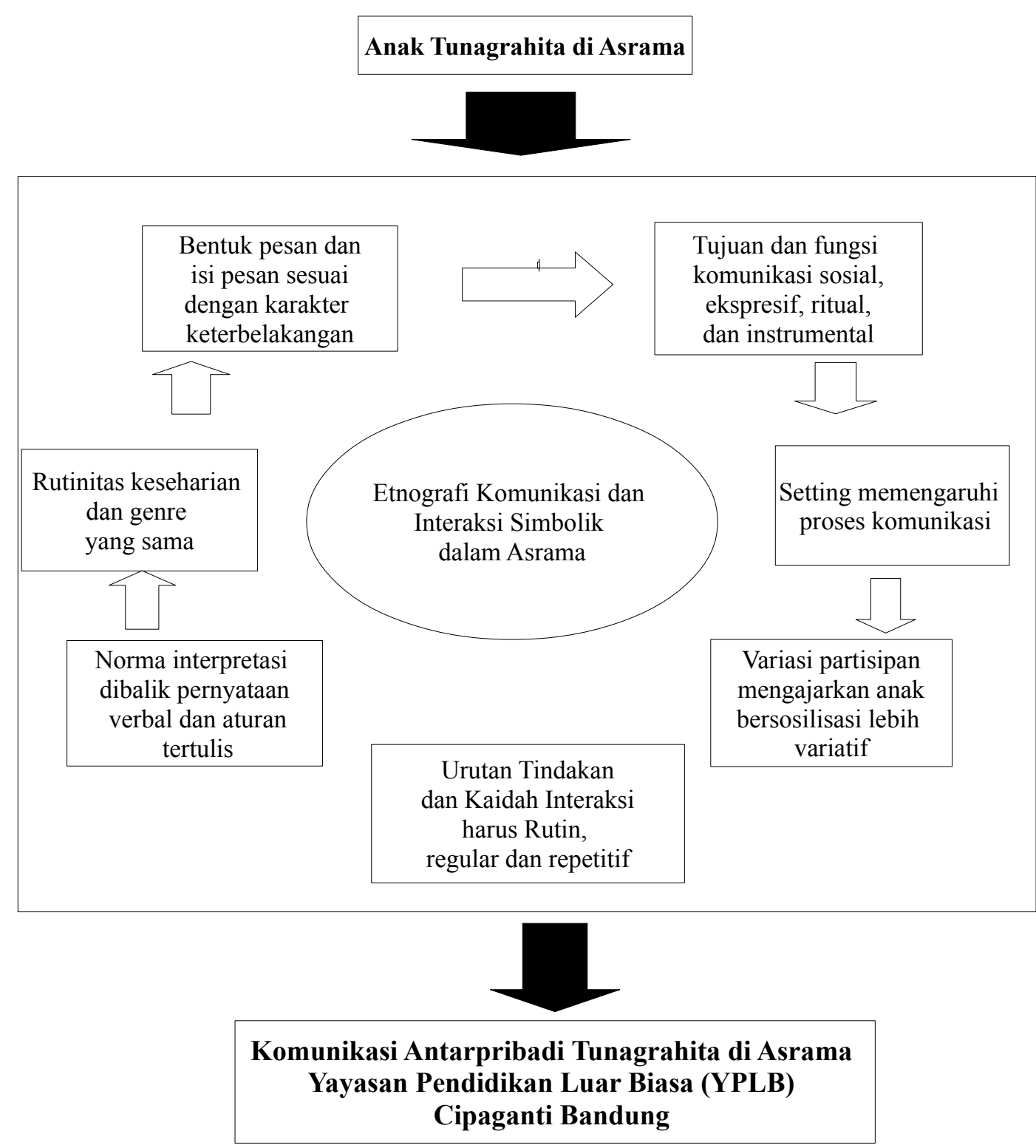

\section{Gambar 3 \\ Skema Etnografi Komunikasi Antarpribadi Tunagrahita di Asrama Yayasan Pendidikan Luar Biasa (YPLB) Cipaganti Bandung}

\section{PENUTUP}

\section{Simpulan}

Keadaan yang terjadi di asrama YPLB Cipaganti merupakan rangkaian peristiwa komunikasi yang melibatkan interaksi simbolik dengan tipe peristiwa komunikasi yang selalu sama, menjadi kebiasaan hidup dan menjadi budaya anak asrama.

Isi pesan berisikan topik percakapan yang sama berdasarkan rutinitas dan ingatan jangka panjangnya. Bentuk pesan menunjukkan kemiripan dalam komunikasi verbal dan nonverbal, sesuai dengan karakter keterbelakangannya dan konstruksi makna dalam lingkungan asrama.

Tujuan atau fungsi komunikasi di setiap tipe peritiwa komunikasi, sebagai komunikasi sosial, komunikasi ekspresif, komunikasi ritual, dan komunikasi instrumental.

Dengan setting yang ada, mereka dapat berkomunikasi antara satu sama lain.

Beragamnya peran partisipan 
memungkinkan anak asrama untuk belajar bersosialisasi.

Anak asrama mampu memahami urutan tindakan dan kaidah interaksi berdasarkan pada $3 \mathrm{R}$, yaitu rutin, regular, repetitive.

$$
\text { Interpretasi pada komunikasi }
$$

antarpribadi tunagrahita di asrama YPLB Cipaganti tersirat di balik pesan verbal maupun peraturan tertulis asrama yang selalu dicoba untuk diterapkan agar anak mengerti dengan aturan dan norma.

\section{Saran}

Tunagrahita merupakan realitas dalam kehidupan masyarakat Indonesia yang termarjinalkan karena stigma negatif yang melekat pada dirinya. Hal ini menyebabkan kurangnya perhatian masyarakat untuk peduli dan mengakui eksistensi mereka. Bentuk perhatian dan kepedulian kita dapat dimulai dengan rasa empati terhadap kondisi mereka dan bersosialisasi dengan mereka. Empati diwujudkan dengan menerima keberadaan mereka, tidak mencemooh, memaklumi perilaku mereka, dan mencoba mengajaknya berinteraksi dan berkomunikasi sebagai bentuk latihan untuk meningkatkan kemampuan adaptif mereka.

Pembinaan tunagrahita memerlukan penanganan terpadu dari berbagai disiplin ilmu, baik itu kedokteran, psikologi, psikiatri, keperawatan, pendidikan khusus, maupun komunikasi. Untuk itu, perlu adanya penelitian lebih lanjut dari berbagai disiplin ilmu tersebut. Khususnya ilmu komunikasi, penelitian tentang komunikasi dan interaksi anak tunagrahita masih sangat jarang, padahal kemampuan adaptif yang utama adalah agar tunagrahita mampu berkomunikasi dengan orang lain. Oleh karenanya perlu dilaukan penelitian lanjutan yang lebih mendalam, mengingat karakteristik komunikasi tunagrahita yang unik dan kompleks.

Asrama Yayasan Pendidikan Luar Biasa (YPLB) Cipaganti Bandung merupakan sebuah sistem masyarakat penyandang tunagrahita dan pengurus asramanya yang dapat menjadi laboratorium kehidupan bagi masyarakat, dan riset serta praktik para akademisi, terutama bidang kedokteran, psikologi, psikiatri, keperawatan, maupun pendidikan khusus.

Meski anak tunagrahita sudah dititipkan di asrama, pihak keluarga sebaiknya tetap memiliki waktu untuk memberikan kasih sayang, misalnya dengan rutin mengunjungi mereka di asrama, mengobrol dengan mereka, untuk menunjukkan bahwa mereka juga memiliki keluarga yang menyayangi mereka.

Perlu adanya kerjasama dari berbagai instansi terkait, khususnya dunia pendidikan khusus dan dinas sosial untuk mengupayakan sarana yang lebih baik bagi sosialisasi mereka, misalnya dengan mendirikan shelter workshop.

\section{DAFTAR PUSTAKA}

\section{Buku:}

Beebe, Steven A. Beebe, Susan J. Redmond, Mark V. (1994). Interpersonal Communication Relating to Others. USA: Allyn and Bacon.

Creswell, J.W. (1998). Qualitative Inquiry and Research Design; Choosing Among Five Traditions. Thousand Oaks. California: Sage. 1998. Qualitative Inquiry and Research Design; Choosing Among Five Traditions. London New Delhi. Sage Publications, Inc.

Delphie. Bandi. (2006). Pembelajaran Anak Tuna Grahita. Bandung: Refika Aditama.

DeVito, Joseph. (1997). Komunikasi Antar Manusia. Jakarta: Professional Books.

Efendi, Mohammad. (2006). Pengantar Psikopedagogik Anak Berkelainan. Jakarta: Bumi Aksara.

Ibrahim, Abd. Syukur. (1992). Panduan Penelitian Etnografi Komunikasi. Surabaya: Penerbit Usaha Nasional.

Kriyantono, Rachmat. (2007). Teknik Praktis Riset Komunikasi. Jakarta: Kencana Perdana Media Grup.

Miles B Matthew dan Huberman A.Michael. (1992). Analisis Data Kualitatif. Penerjemah Rohendi Rohidi. Jakarta : UI Press. 
Moleong, Lexy J. (1993). Metodologi Penelitian Kualitatif. Bandung: Remaja Rosdakarya.

Mulyana, Deddy. (2005). Ilmu Komunikasi Suatu Pengantar. Bandung: Remaja Rosdakarya.

Mulyana, Deddy. (2006). Metodologi Penelitian Kualitatif. Bandung: Remaja Rosdakarya.

Rakhmat, Jalaluddin. (1999). Psikologi Komunikasi. Bandung: Remaja Rosdakarya.

Somantri, Sutjihati. (2007). Psikologi Anak Luar Biasa. Bandung: Refika Aditama.

Sukidin dan Basrowi. (2002). Metode Penelitian Kualitatif Perspektif Mikro. Surabaya : Insan Cendikia.

Tubbs, Stewart L dan Moss, Sylvia. (2005). Human Communication Prinsip-Prinsip Dasar. Deddy Mulyana (ed). Bandung:
Remaja Rosdakarya.

West, Richard dan Turner, Lynn H. (2006). Understanding Interpersonal Communication Making Choices in Changing Time. United States: Wadsworth Publishing Company.

\section{Sumber lainnya:}

Disertasi

Delphie, Bandi. (2003). Bimbingan Pengembangan Perilaku adaptif Siswa Tunagrahita dengan Memanfaatkan Permainan Terapeutik dalam Pembelajaran. Disertasi. Program Pascasarjana Universitas Pendidikan Indonesia. Bandung. 